\title{
Analisis Efektifitas Biaya Kloramfenikol dan Siprofloksasin Pada Pengobatan Tifoid di RSUD Datu Beru Kota Takengon Aceh Tengah
}

\author{
Afdalul Magfirah \\ Stikes Payung Negri Aceh Darussalam \\ afdalul.magfirah@gmail.com \\ DOI : 10.32672/jss.v7i2.1578
}

\begin{abstract}
ABSTRAK
Telah dilakukan analisis efektifitas biaya kloramfenikol dan siprofloksasin pada pengobatan tifoid di RSUD Datu Beru kota Takengon Aceh Tengah dari bulan januari sampai Desember 2012. Tujuan penelitian adalah untuk mengetahui antibiotik yang lebih "cost efektive" antara pasien yang menggunakan kloramfenikol dan pasien yang menggunakan siprofloksasin. Penelitian ini dilakukan secara retrospektif, dari rekam medik pasien yang dirawat inap dari Januari sampai Desember 2012. Komponen biaya yang dikumpulkan meliputi biaya kelas perawatan, biaya laboratorium, biaya tindakan paramedis, biaya obat, biaya medis langsung, dan biaya antibiotik. Hasil penelitian menunjukan bahwa antibiotik yang paling "cost efektive" secara ACER dan ICER adalah kelompok terapi yang menggunakan antibiotik siprofloksasin dengan penghematan biaya Rp3884,6/pasien.
\end{abstract}

Kata Kunci: Efektifitas biaya, Kloramfenikol, Siprofloksasin, Demam Tifoid.

\section{PENDAHULUAN}

Masalah biaya kesehatan (rumah sakit, dokter, obat, pemeriksaan laboratorium dan lain-lainnya) sejak beberapa tahun terakhir telah banyak menarik perhatian, tidak hanya di dalam negeri, tetapi juga di luar negeri. Biaya pelayanan kesehatan yang dirasakan semakin meningkat sebagai akibat dari berbagai faktor, yaitu perubahan pola penyakit dan pola pengobatan, peningkatan penggunaan teknologi canggih, populasi pasien usia lanjut yang semakin banyak dengan konsekuensi meningkatnya penggunaan obat, adanya obatobat baru yang lebih mahal dan perubahan pola pengobatan, meningkatnya permintaan masyarakat dan perubahan ekonomi secara global.

Dalam upaya menjadikan pelayanan kesehatan lebih efisien dan ekonomis, Apoteker ditantang untuk mampu melakukan penilaian menyeluruh terhadap suatu obat baik dari segi efektifitas obat maupun dari segi nilai ekonomisnya. Untuk itu diperlukan bekal pengetahuan tentang prinsip-prinsip farmakoekonomi dan keterampilan yang memadai dalam melakukan evaluasi hasil studi farmakoekonomi (Eisenberg,1994; Trisna, 2010).

Salah satu penyakit yang memerlukan evaluasi farmakoekonomi baik dari segi efektifitas obat maupun dari segi nilai ekonomisnya adalah demam tifoid. Demam tifoid merupakan penyakit sistemik yang ditandai dengan demam dan nyeri abdomen dan muncul akibat infeksi Salmonella typhi dan Salmonella paratyphi (Fauci, 2008). 
Pemilihan antibiotika alternatif menjadi faktor utama yang harus diperhatikan selain faktor biaya. Efisiensi ekonomi kesehatan dilakukan dengan tujuan agar sumber daya yang tersedia dapat digunakan untuk meningkatkan dan menjamin kesehatan masyarakat seoptimal mungkin. Efisiensi juga berhubungan dengan biaya satuan sumber daya yang digunakan dan hasilnya, dengan demikian terlihat adanya maksimalisasi luaran dan pemilihan alternatif proses pelayanan kesehatan yang terbaik. Untuk mencapai tujuan tersebut dapat dilakukan dengan analisis ekonomi kesehatan yang disebut analisis efektivitas biaya. Cost-effectiveness analysis merupakan suatu penelitian untuk menemukan cara dalam meningkatkan efisiensi dan memobilisasi sumber dana dan dapat dipergunakan untuk membantu mengembangkan pemikiran-pemikiran khusus tanpa mengabaikan aspek-aspeksosial dari sektor kesehatan itu sendiri. (Gani, 1999; Schulman, 2000).

Penelitian ini dilakukan di Rumah Sakit Umum Daerah (RSUD) Datu Beru Kota Takengon. Sumber data berupa rekamedik pasien demam tifoid yang menjalani rawat inap di Bagian Penyakit dalam RSUD Datu Beru kota Takengon Aceh Tengah selama periode Januari - Desember 2012. Selain itu juga digunakan buku tarif pelayanan tahun 2012.

Data yang didapatkan kemudian dianalisis dengan menggunakan rumus Average Cost EffectivenesRatio (ACER) yang dihitung berdasarkan jumlah biaya antibiotik yang dikeluarkan pasien tifoid terhadap efektifitas penggunaan antibiotik, kemudian dilanjudkan dengan ICER (Intremental Cost Effectivenees Ratio) yang digunakan untuk mendeterminasi biaya tambahan dan pertambahan efektivitas dari suatu terapi di bandingkan dengan terapi yang paling baik.

\section{METODE PENELITIAN}

Penelitian ini adalah penelitian cross-sectional, yaitu penelitian yang dilakukan dengan cara survei atau pengumpulan data sekaligus pada satu waktu (Notoatmodjo, 2005).

\section{Kriteria Inklusi}

Kriteria inklusi dalam penelitian ini adalah Pasien demam tifoid yang dirawat inap Bagian Penyakit Dalam Rumah Sakit Umum Datu Beru kota Takengon Aceh tengah selama periode Januari - Desember 2012.

\section{Kriteria Eksklusi}

1. Pasien demam tifoid yang menghentikan pengobatan sebelum dinyatakan sembuh oleh dokter.

2. Pasien demam tifoid yang diberikan antibiotika kombinasi.

3. Data pasien yang tidak lengkap, hilang, dan tidak jelas terbaca.

4. Pasien pulang atas permintaan sendiri/pulang paksa

5. Pasien tifoid dengan penyulit.

6. Pasien lanjut usia

\section{Pengolahan dan Analisis Data}

Pengumpulan data berupa Data karakteristik pasien yang meliputi; nomor rekam medik, jenis kelamin, dan umur pasien. Data klinis meliputi; diagnosa utama, waktu hilangnya demam, dan gejala ikutan dan lama hari rawat. Data biaya meliputi; biaya 
Afdalul Magfirah

rawatan, biaya laboratorium, biaya tindakan medis, biaya obat, biaya antibiotik dan biaya medis langsung.

Efektifitas biaya dianalisis dengan menggunakan rumus Average Cost EffectivenesRatio (ACER) yang dihitung berdasarkan jumlah biaya antibiotik yang dikeluarkan pasien tifoid terhadap efektifitas penggunaan antibiotik

\section{HASIL PENELITIAN}

\section{Karakteristik Subyek Penelitian}

Dari hasil didapatkan bahwa jumlah pasien yang menggunakan antibiotika Siprofloksasin lebih besar dibandingkan dengan antibiotika kloramfenikol, ditinjau dari persentase jumlah penelitian yang telah dilakukan. Ditinjau dari jenis kelamin yaitu sebanyak 54,54 \% pasien laki-laki dan 45,45\% pasien perempuan. penderita demam tifoid mengalami peningkatan jumlah kasusnya pada kelompok umur dengan jumlah pasien terbanyak yaitu umur 31-40 tahun dengan persentase sebesar $36 \%$ dengan rata-rata 33,68 Pada Karateristik umur pada Pasien dalam penelitian ini terdapat umur yang banyak didapat yaitu pada umur 31 tahun dan simpangan baku sebesar 11,283 dilihat dari nilai simpangan baku dapat disimpulkan bahwa terdapat penyebaran umur pasien pada demam tifoid bervariasi atau tidak sama.

\section{Tabel 1. Data karakteristik penelitian}

\begin{tabular}{|c|c|c|c|c|}
\hline No. & $\begin{array}{c}\text { Parameter/ } \\
\text { variabel }\end{array}$ & Jumlah & Persentase \% & $\mathbf{P}$ \\
\hline 1. & $\begin{array}{l}\text { Jenis } \\
\text { Antibiotika } \\
\text { - Kloramfenikol } \\
\text { - Siprofloksasin }\end{array}$ & $\begin{array}{l}19 \\
25\end{array}$ & $\begin{array}{l}43,18 \% \\
56,82 \%\end{array}$ & 0.000 \\
\hline 2. & $\begin{array}{l}\text { Jenis Kelamin } \\
\text { - Laki-laki } \\
\text { - Perempuan }\end{array}$ & $\begin{array}{l}23 \\
21\end{array}$ & $\begin{array}{l}52,3 \% \\
47,7 \%\end{array}$ & 0,217 \\
\hline 3. & $\begin{array}{l}\text { Umur } \\
-<20 \text { tahun } \\
-21-30 \text { tahun } \\
-31-40 \text { tahun } \\
-41-50 \text { tahun } \\
-51-60 \text { tahun } \\
X \pm S D \\
\text { Mode }\end{array}$ & $\begin{array}{c}7 \\
9 \\
16 \\
8 \\
4 \\
33,68 \pm 11,282 \\
31\end{array}$ & $\begin{array}{c}15,90 \% \\
20,45 \% \\
36,36 \% \\
18,18 \% \\
9,09 \%\end{array}$ & 0,066 \\
\hline
\end{tabular}


Tabel 2. Efektifitas pada pengobatan demam tifoid yang menggunakan antibiotika kloramfenikol dan siprofloksasin di bagian rawat inap RSUD Datu Beru Kota Takengon Aceh Tengah.

\begin{tabular}{lccc}
\hline & $\begin{array}{c}\text { Kloramfenikol } \\
(\mathrm{n}=19) \\
(\mathrm{x} \pm \mathrm{SD})\end{array}$ & $\begin{array}{c}\text { Siprofloksasin } \\
(\mathrm{n}=25) \\
(\mathrm{x} \pm \mathrm{SD})\end{array}$ & $\mathrm{P}$ \\
\hline $\begin{array}{l}\text { Hilangnya demam } \\
\text { perhari }\end{array}$ & $3.79 \pm 0.918$ & $2.88 \pm 0.526$ & 0.000 \\
$\begin{array}{l}\text { Hilangnya gejala } \\
\text { ikutan perhari }\end{array}$ & $8.21 \pm 0,855$ & $3.44 \pm 0,507$ & 0.000 \\
\begin{tabular}{l} 
Lama perawatan \\
\hline
\end{tabular} & $12.21 \pm 1.584$ & $5.04 \pm 0.889$ & 0.000 \\
\hline
\end{tabular}

Dilihat dari lama perawatan, hilangnya demam dan hilangnya gejala ikutan antara pasien demam tifoid yang menggunakan kloramfenikol dan siprofloksasin, tampak bahwa pasien yang menggunakan kloramfenikol lebih cepat proses pengobatannya dibandingkan dengan pasien yang menggunakan siprofloksasin. Maka dapat dikatakan bahwa kloramfenikol menunjukan efektivitas pengobatan yang lebih baik dibandingkan siprofloksasin.

\section{Perhitungan Efisiensi Biaya}

Adanya perbedaan biaya satuan pada pasien demam tifoid yang menggunakan kloramfenikol lebih mahal dibandingkan dengan pasien yang menggunakan siprofloksasin hal ini disebabkan karena lamanya hari perawatan untuk pasien yang menggunakan kloramfenikol lebih panjang dibandingkan dengan lamanya hari rawat pasien yang menggunakn siproflosasin, sehingga membuat tingginya biaya satuan yang harus dikeluarkan pasien yang menggunakan antibiotika kloramfenikol.

Tabel 3. Perbandingan efisiensi biaya satuan pengobatan demam tifoid menggunakan antibiotika kloramfenikol dan siprofloksasin di bagian rawat inap RSUD Datu Beru Kota Takengon Aceh Tengah.

\begin{tabular}{|l|c|c|c|}
\hline \multicolumn{1}{|c|}{ Jenis biaya } & Kloramfenikol* & Siprofloksasin** & P \\
\hline $\begin{array}{l}\text { Biaya kelas } \\
\text { perawatan }(\mathrm{X} \pm \mathrm{SD})\end{array}$ & $1.184 .421,05 \pm 205701,21$ & $488.880,00 \pm 143546,89$ & 0.000 \\
\hline $\begin{array}{l}\text { Biaya laboratorium } \\
(\mathrm{X} \pm \mathrm{SD})\end{array}$ & $108000,00 \pm 26529,25$ & $91000,00 \pm 19487,30$ & 0.071 \\
\hline $\begin{array}{l}\text { Biaya tindakan } \\
\text { paramedis }(\mathrm{X} \pm \mathrm{SD})\end{array}$ & $185.684,21 \pm 28676,99$ & $85.240,00 \pm 26070,37$ & 0.000 \\
\hline $\begin{array}{l}\text { Biaya obat } \\
(\mathrm{X} \pm \mathrm{SD})\end{array}$ & $820.436,84 \pm 132512$ & $575.500,00 \pm 116530$ & 0.000 \\
\hline Biaya total medis & $2.955 .823,68 \pm 1.095 .868,19$ & $1.648 .512,00 \pm$ & 0.000 \\
\hline
\end{tabular}


Afdalul Magfirah

\begin{tabular}{|l|c|c|c|}
\hline langsung $(\mathrm{X} \pm \mathrm{SD})$ & & 918393,44 & \\
\hline $\begin{array}{l}\text { Biaya Antibiotik } \\
(\mathrm{X} \pm \mathrm{SD})\end{array}$ & $174.576 \pm 25881,18$ & $3.262 \pm 560,00$ & 0.000 \\
\hline
\end{tabular}

Keterangan :

- $\quad *$ Kloramfenikol $(\mathrm{n}=19)$

- $\quad * *$ Siprofloksasin $(\mathrm{n}=25)$

Tabel 4. Hasil analisa Cost Effectiveness terhadap biaya antibiotik pasien demam tifoid yang dirawat di instalasi rawat inap penyakit dalam RSUD Datu Beru Takengon Aceh Tengah.

\begin{tabular}{|c|c|c|c|c|}
\hline No & Kelompok terapi & Biaya/hari (Rp) $(\mathrm{C})$ & Outcomes (E) & ACER (C/E) \\
\hline 1. & Kloramfenikol & $174.576,32$ & 12,21 & $14.297,81$ \\
\hline 2. & Siprofloksasin & 3.262 & 5,04 & 647,2 \\
\hline
\end{tabular}

Tabel.5 Hasil ICER terhadap biaya antibiotik pasien demam tifoid yang dirawat di instalasi rawat inap penyakit dalam RSUD Datu Beru Takengon Aceh Tengah

\begin{tabular}{ccccccc}
\hline No & $\begin{array}{c}\text { Kelompok } \\
\text { terapi }\end{array}$ & $\begin{array}{c}\text { Biaya } / \text { hari } \\
(\mathbf{R p})(\mathbf{C})\end{array}$ & $\begin{array}{c}\text { \% Total } \\
\text { Outcome (E) }\end{array}$ & $\Delta \mathbf{C}$ & $\Delta \mathbf{E}$ & $\begin{array}{c}\text { ICER } \\
\mathbf{~ C / \Delta E}\end{array}$ \\
\hline 1. & Kloramfenikol & $174.576,32$ & 64,26 & & & \\
2. & Siprofloksasin & 3.262 & 20,16 & $171.314,32$ & 44,1 & 3884,6 \\
\hline
\end{tabular}

\section{PEMBAHASAN}

Jenis antibiotik yang digunakan pada terapi demam tifoid di RSUD Datu Beru Takengon adalah bentuk tunggal dan bentuk kombinasi, dimana antibiotik yang paling sering digunakan untuk demam tifoid ini lebih sering dalam bentuk tunggal dibandingkan dalam bentuk kombinasi. Beberapa antibiotik yang digunakan antara lain adalah kloramfenikol, siprofloksasin, seftriakson, sefotaksim, ampisilin dan amoksilin, namun pada penelitian ini hanya membandingkan efektifitas penggunaan antibiotika kloramfenikol dan siprofloksasin, di RSUD Datu Beru kloramfenikol merupakan antibiotika lini pertama yang digunakan untuk pengobatan demam tifoid, sedangkan siprofloksasin merupakan antibiotik lini ke tiga.

Berdasarkan hasil yang telah didapatkan dalam penelitian ini bahwa siprofloksasin adalah antibiotik yang paling banyak digunakan dibandingkan kloramfenikol yaitu terdiri dari $56,82 \%$ pasien yang menggunakan siprofloksasin dan $43,18 \%$ pasien yang menggunakan kloramfenikol, hal ini disebabkan karena harganya yang relatif lebih murah dan efektifitasnya yang baik dibandingkan dengan antibiotik yang lainnya. Faktor harga 
yang murah dan kenyamanan pemakaian, dimana golongan siprofloksasin cukup diminum dua kali sehari mengakibatkan pemakaian siprofloksasin amat meningkat.

Di Amerika, terjadi ledakan salmonella yang resisten terhadap fluorokuinolon (Olsen, 2001). Namun, data dari Laboratorium Klinik Mikrobiologi FKUI tahun 2004 menunjukkan seluruh Salmonella typhi yang diisolasi masih sensitif terhadap siprofloksasin (Sudiro, 2004). Begitu juga dengan antibiotik yang digunakan di RSUD Datu Beru Takengon yaitu masih menggunakan siprofloksasin sebagai pilihan terapi untuk demam tifoid.

Berdasarkan Jenis Kelamin Persentase yang didapatkan antara pasien demam tifoid antar laki-laki dan perempuan selama periode penelitian tidak jauh berbeda hanya selisih 2 orang, dimana pasien laki-laki lebih banyak dari pada pasien perempuan, yaitu laki-laki 52,3\% sedangkan perempuan adalah 47,7\%, hal ini sesuai dengan literatur penyakit demam tifoid pada laki-laki 2 sampai 3 kali lebih besar dibandingkan dengan perempuan (hadinegoro, 2008). Berdasarkan penelitian yang dilakukan oleh Lili Musnelina di rumah sakit Fatmawati Jakarta pada tahun 2001-2002, dari 182 responden demam tifoid yang diperiksa, demam tifoid lebih banyak diderita oleh laki-laki yaitu $55,49 \%$ dan perempuan $44,51 \%$.

Faktor umur merupakan determinan penting yang menentukan manifestasi klinis dari demam tifoid, dimana pengaruh umur pada insiden berhubungan dengan mekanisme imun seluler dan humoral. Demam tifoid dapat terjadi pada setiap kelompok umur tetapi lebih sering terjadi pada usia 3-19 tahun, (Soegijanto, 2002). Pada penelitian ini demam tifoid paling banyak terjadi pada umur 31-41 tahun, hasil yang didapatkan dalam penelitian ini tidak sesuai dengan literatur yang didapatkan hal ini mungkin disebabkan karena pada usia 31-40. Menurut penelitian Simanjuntak, C.H. dkk (1989) terdapat 77\% penderita demam tifoid pada umur 3-19 tahun dan tertinggi pada umur 10-15 tahun dengan insidens rate 687,9 per 100.000 penduduk (Hadinegoro, 2008).

Rata-rata lama hari rawat inap pasien yang menggunakan antibiotika kloramfenikol adalah 12,21 hari. Dalam literatur dikatakan bahwa lama hari rawat untuk pasien demam tifoid yang menggunakan antibiotik kloramfenikol berkisar antara 17-23 hari, dengan dosis dewasa 4 x 500mg sehari oral atau intravena ( Noer S, 1996). Dalam penelitian ini terlihat bahwa hasil yang didapatkan berbeda dengan literatur, hal ini kemungkinan disebabkan oleh kondisi dari pasien demam tifoid yang dirawat di RSUD Datu Beru telah menunjukan perbaikan yang lebih cepat sehingga tidak dibutuhkan waktu perawatan yang lebih lama.

Rata-rata hari rawat inap pasien yang menggunakan antibiotika siprofloksasin adalah 5,04 hari. Menurut Kinnear (1971) yang dikutip oleh Hadisaputro bahwa perawatan di rumah sakit sangat dianjurkan pada penyakit demam tifoid dengan tujuan untuk menghindari komplikasi-komplikasi yang tidak diinginkan. Namun menurut Christie (1980) yang dikutip oleh Hadisaputro setelah bebas demam pasien tidak selalu harus berada di rumah sakit sampai 10 hari bebas demam. Hal ini kemungkinan berkaitan dengan biaya yang harus dikeluarkan oleh pasien Hadisaputro (1990).

Rata-rata hilangnya demam pada pasien demam tifoid yang menggunakan antibiotika kloramfenikol dan siprofloksasin yaitu pada hari ke 3,79 dan rata-rata pada hari ke 2,88. Menurut Noer (1996) dengan penggunaan kloramfenikol pada demam tifoid akan menghilang setelah 5 hari dengan dosis dewasa 4 kali $500 \mathrm{mg}$ sehari oral atau intravena selama 7 hari. Hilangnya gejala ikutan dialami oleh pasien demam tifoid yang 
menggunakan antibiotika kloramfenikol rata-rata pada hari ke 8,21 dan pada hari ke 3,44 bagi pasien yang menggunakan antibiotik siprofloksasin. Gejala ikutan yang dimaksud dalam hal ini adalah nyeri perut, sakit kepala, pusing, mual, muntah, nyeri pada uluhati, nafsu makan menurun. Hilangnya keluhan terhadap gejala ikutan kemungkinan akan berbeda pada setiap pasien demam tifoid dengan pemberian antibiotika yang berbeda.

Berdasarkan data distribusi biaya penggunaan antibiotik didapatkan bahwa siprofloksasin adalah antibiotik dengan rata-rata harga yang paling murah dengan standar deviasi yang paling kecil itu sebabnya pemakaian antibiotik di bangsal jauh lebih besar dibandingkan dengan kloramfenikol.

Untuk biaya kelas perawatan berdasarkan antibiotik yang digunakan oleh pasien didapatkan hasil dimana biaya kelas perawatan yang tertinggi terdapat pada kelompok terapi yang menggunakan antibiotik kloramfenikol yaitu sebesar Rp 1.184.421,05, hal ini disebabkan karena lamanya hari rawat pasien yang menggunakan kloramfenikol sehingga membuat biaya juga semakin tinggi, dimana untuk bangsal tarif sama permalamnya yaitu Rp 97.000,/ malam plus visite dokter.

Sedangkan untuk biaya laboratorium didapatkan rata-rata dan juga standar deviasinya pada masing-masing pasiennya juga berbeda, yaitu kloramfenikol Rp. 10.8000,00/pasien dan Rp. 91.000,00/pasien untuk siprofloksasin, tidak mutlak sama meskipun pasien sama-sama berada dibangsal dengan indikasi penyakit yang sama, dimana setiap pasien memiliki kondisi berbeda dengan kebutuhan pemeriksaan labor yang berbeda.

Biaya obat pada penelitian ini memperlihatkan adanya perbedaan secara bermakna terhadap biaya obat antara pasien yang menggunakan antibiotik kloramfenikol dengan pasien yang menggunakan siprofloksasin, hal ini sangat berhubungan dengan lama hari rawatan yang jauh berbeda antara pasien yang menggunakan antibiotik kloramfenikol dan pasien yang menggunakan antibiotik siprofloksasin, sehingga biaya obat juga sangat jauh berbeda dimana rata-rata biaya obat pada pasien yang menggunakan antibiotik kloramfenikol Rp. 820.436,84/hari dan Rp. 575.500,00/hari untuk pasien yang menggunakan antibiotik siprofloksasin.

Biaya penggunaan antibiotik kloramfenikol lebih tinggi dari Siprofloksasin ini disebabkan karena harga dari satuan siprofloksasin Rp 350/tab jauh lebih murah dibandingkan dengan kloramfenikol yaitu Rp 7500/vial, antibiotik kloramfenikol diberikan secara parenteral sedangkan antibiotik siprofloksasin diberikan secara oral, hal ini juga menjadi penyebab tingginya biaya antibiotik pada kloramfenikol karena memang pada dasarnya obat-obatan dalam bentuk parenteral lebih mahal dibandingkan dengan obat oral.

Biaya total medis langsung sudah mencakup semua biaya-biaya diatas seperti, biaya kelas rawatan, laboratorium, tindakan paramedis, biaya obat, dan biaya antibiotik. Hasil dari analisa biaya total medis langsung terlihat bahwa kelompok terapi pada pasien demam tifoid yang menggunakan kloramfenikol yang biaya medis langsungnya paling tinggi, hal ini disebabkan karena lama hari rawat pasien yang menggunakan kloramfenikol lebih panjang bila dibandingkan dengan lama hari rawat pasien yang menggunakan siprofloksasin, sehingga membutuhkan tindakan para medis yang lebih lama lagi hal ini cendrung meningkatkan biaya yang harus dikeluarkan oleh pasien menjadi lebih banyak termasuk biaya oabat dan biaya kelas perawatan.

Pengobatan demam tifoid sebenarnya cukup dengan pemberian antibiotik sebagai pengobatan kausatif, tetapi kenyataannya justru mengobati gejala simptom sehingga 
membutuhkan biaya yang lebih besar. Terbukti bahwa obat merupakan salah satu komponen penting dalam sistem pelayanan kesehatan, sehingga biaya obat yang murah menjadi harapan setiap orang.

Dari hasil analisa penelitian yang telah dilakukan menunjukan bahwa kelompok yang paling cost effektive adalah kelompok terapi yang menggunakan siprofloksasin, sedangkan kelompok terapi yang paling efektif secara ACER dan ICER adalah siprofloksasin dengan penghematan biaya Rp. 3884,6 /pasien.

\section{PENUTUP}

Hasil penelitian ini dapat dismpulkan bahwa penggunaan siprofoksasin lebih menghemat biaya dalam pengobatan tifoid.

\section{DAFTAR PUSTAKA}

Eisenberg, J. M., Schulman, K. A., Glick, H. \&Koffer,H.1994. Pharmacoeconomics: Economic Evaluation of Pharmaceuticals. In: Strom BL,ed, Pharmacoepidemiology. 469-93.

Gani , A. T. 1999. Analisis Ekonomi dalam Pelayanan Kesehatan. Jakarta: Fakultas Kesehatan Masyaraklat Universitas Indonesia.

Hadisaputro, S.1990.Beberapa faktor yang memberipengaruh terhadap kejadian perdarahan dan atauperforasi usus pada demam tifoid. Direktorat Pembinaan. Jakarta: Penelitian pada Masyarakat Departemen Pendidikan dan Kebudayaan.

Hadinegoro, S. R. 2008. Masalah Multi Drug Resisten pada Demam Tifoid Anak. Cermin Dunia Kedokteran. 124: 5-8

Notoatmojo, S. Metodologi Penelitian Kesehatan. 2005. Ed. Revisi. Jakarta: PT Rineka Cipta.

Noer S. Dkk. 1996. Buku Ajar Ilmu Penyakit Dalam. Jakarta: Balai Penerbit FKUI.

Olsen. S. J., DeBess. E. E., McGivern. T. E., et al. 2001. A Nosocomial Outbreak of Fluoroquinolone-Resistant Salmonella Infection. Vol.344

Schulman, K. A., Glick, H., \& Polsky, D. 2000. Pharmacoecomonics: Ecomonics evaluation of pharmaceuticals.In Strom BL (eds). Pharmacoepidemiology. 573601

Trisna, Y. 2010. Aplikasi Farmakoekonomi. Diakses 23 Maret 2013. http://www.Ikatan apotek Indonesia.com. 